\title{
LIVING UNITY? \\ ON THE ECUMENICAL MOVEMENT AND GLOBALISATION
}

Dirk J Smit

Systematic Theology

Stellenbosch University

\begin{abstract}
The paper is an attempt to understand and describe how processes of globalisation are impacting on the Ecumenical Movement. It argues that the Ecumenical Movement has a concern for the one world based on a normative, theological vision, nowadays often described with terms related to or derived from oikos, for the household of life in the economy of the Living Triune God (part 1). During the $20^{\text {th }}$ century, both Faith and Order and Life and Work attempted to give content to this vision of unity or koinonia, albeit in diverse and sometimes conflicting ways (part 2). Since Canberra (1991) these two major ecumenical initiatives together attempted to unite their respective ecclesiological and ethical concerns in a process called "Ecclesiology and Ethics". During three Consultations, on "Costly Unity", "Costly Commitment" and "Costly Obedience" respectively, important implications for both church and ethics came to the fore (part 3). In the light of this process, some conclusions regarding globalisation and life in community (part 4) and implications for South African society (part 5) are drawn.
\end{abstract}

\section{1. 'And'?}

The "and" between "Ecumenical Movement" and "globalisation" in the theme given to me can be interpreted in many ways. ${ }^{1}$ My initial intuition was to focus on the way the Ecumenical Movement responds to, and could or should respond to globalisation. The Ecumenical Movement - understood here in a narrow, fairly technical sense as the (mainly Protestant and Orthodox) World Council of Churches and initiatives with which it is involved - is indeed engaged in several major projects dealing with questions and themes normally related to globalisation - including mass communication, ${ }^{2}$ technology, ${ }^{3}$ the world economic order, ${ }^{4}$ civil

1. This paper was read during a joint inter-disciplinary consultation of the Ecumenical Foundation of Southern Africa (EFSA) and the Evangelische Akademie, Tutzing, Bavaria, in Tutzing, Germany, 5-7 June 2000, on "Consequences of Globalisation for Germany and South Africa".

2. See e.g. Chris Arthur, The globalization of communications. Some Religious Implications (Geneva: WCC 1998).

3. For an overview, see David J Pullinger, “Technology," Dictionary of the Ecumenical Movement, ed. by. Lossky, N, Bonino, JM, Pobee, J et al (Geneva: WCC 1991), 973-976.

4. See e.g. Economics: A Matter of Faith, CCPD Documents No. 11 (Geneva: WCC 1988) and Christian Faith and World Economy Today (Geneva: WCC 1992). These discussions include issues like work (see e.g. Howard Davis \& David Gosling, eds., Will the Future Work? Values for Emerging Patterns of Work and Employment, Geneva: WCC 1986), the role of transnational corporations (see e.g. Churches Report on Transnational Corporations, CCPD Documents No.7, 1986), the way women are affected by poverty (see e.g. What about ... Women in Poverty in Europe, Geneva: WCC 1992), the role of the church under, for and with the poor (see e.g. the many publications by Julio de Santa Ana, like Towards a Church of the Poor, Geneva: WCC 1982), the international debt crisis (see e.g. The Debt Crisis and Brazil: A Case Study, CCPD Documents No. 10, Geneva: WCC 1987), ecology and economy (see e.g. Sustainable Growth - A Contradiction in Terms? Economy, Ecology and Ethics after the Earth Summit, Geneva: The Visser't Hooft Endowment Fund, 1993), the importance of life from the perspective of faith (see e.g. Sacrifice and Humane 
society, ${ }^{5}$ the integrity of creation, ${ }^{6}$ respect for difference, context, culture and locality ${ }^{7}$ - and it would certainly have been instructive to focus on some of these study projects and activities. In general, the underlying question would then have been how the Ecumenical Movement is interpreting, evaluating and, where necessary, challenging globalisation.

It may be, however, at least equally important also to reverse the question, and to understand the relationship implied in the "and" as a challenge to the Ecumenical Movement itself. What is the effect of globalisation on the Ecumenical Movement, and what could future effects be? What is happening with the Ecumenical Movement as part of the dramatic worldwide shifts called globalisation? How is the Ecumenical Movement being challenged by globalisation?

Ecumenism is concerned with the world. This has always been the case in history, whether in earlier centuries, or during the self-consciously ecumenical twentieth-century. The Greek word oikoumene refers to the whole inhabited earth. From its inception, the World Council of Churches accordingly understood its own focus as "everything that relates to the whole task of the whole church to bring the gospel to the whole world".

This ecumenical concern for the world is clearly based on a normative vision. From the perspective of Christian faith, the Ecumenical Movement sees the world in a particular light of what it is, could be, should be, and will become. Its global concern is more than formal. It is integrally embedded in its faith, in its convictions concerning the origin and destiny of the world. The "and" between ecumenical and global is therefore completely natural, based on the church's faith and theology.

In recent years, attempts have increasingly been made to use the metaphor of oikos, household, implied in the oikoumene, to develop this vision further. ${ }^{9}$ Ecumenical leaders and theologians are deliberately relating the oikoumene of the church to the oikounomia or fullness of the life of the Trinitarian God, to be reflected in the life of the church. ${ }^{10}$ The oikoumene is furthermore related to the global political and economic realities, critically discussed from the

Economic Life, Geneva: WCC 1992), church statements on economic issues (see e.g. Aart van den Berg, Churches Speak out on Economic Issues. A Survey of Several Statements, Geneva: WCC 1990), Biblical perspectives (Roelf Haan, The Economics of Honour. Biblical Reflections on Money and Poverty, Geneva: WCC 1991), and the question whether the global economy should become a confessional issue (see e.g. Ulrich Duchrow, Global Economy: A Confessional Issue for the Churches, Geneva: WCC 1987).

5. See e.g. five overview and introductory articles, with further literature, in The Ecumenical Review Vol 46, No. 1, 1994 (by Julio de Santa Ana, Israel Batista, Ulrich Duchrow, Muto Ichiyo and Konrad Raiser).

6. See, as introductions with literature, Douglas John Hall, "Creation," and D Preman Niles, "Justice, Peace and the Integrity of Creation, in Dictionary of the Ecumenical Movement”, 246-249, and 557-559, respectively.

7. For obvious reasons, the theme of "culture" has played a major role in almost all activities of the Ecumenical Movement. In this process, related issues, like contextualisation, dealing with differences and pluralities, and questions of identity, have continuously been present. For an introduction, with references, see Choan-Seng Song, "Culture," in Dictionary of the Ecumenical Movement, 257-259. With the growing impact of globalisation, these discussions are obviously affected in complex and dramatic ways.

8. See Konrad Raiser, Ecumenism in Transition (Geneva: WCC, 1991), 84 with reference in footnote 14.

9. According to Konrad Raiser, 87, Ernst Lange, in "The malaise in the ecumenical movement. Notes on the present situation," The Ecumenical Review Vol. 23, 1971, 8 was the first one to use "household" as a translation of "oikoumene." Since then, many people and studies have done that in great detail, see e.g. Thomas F. Best \& Martin Robra, eds., Costly Commitment: Ecclesiology and Ethics (Geneva: WCC 1995), 43-45.

10. In his speech at the Vancouver Assembly, Secretary-General Philip Potter explicitly linked the form of the church as a fellowship with the metaphor of "house" or "household." Since then, many people have developed this idea further. In his important interpretive essay on the Harareby Assembly, Lewis S Mudge uses this as the key to unlock and understand the present state of the discussion, see "Towards a Hermeneutic of the Household: 'Ecclesiology and Ethics' after Harare," The Ecumenical Review Vol. 51, 1999, 304-314. 
perspective of the political economy of the Holy Spirit, ${ }^{11}$ as well as to the habitable earth and, in fact, the whole of creation and ecology. ${ }^{12}$ The oikos of church, political economy and earth all together form part of the one household of life in the economy of the Living Triune God.

The household-metaphor is relational - whether in the divine society of the Trinity, in the church, in the political economy of the world, or in the fullness of creaturely life. The moral vision of the Ecumenical Movement for these inter-related households concerns the nature of the relationships within and amongst them.

\section{In search of koinonia}

Has it been possible for the Ecumenical Movement to describe the nature of these relationships more fully, to give content to the "household of life"? Throughout the twentieth century, the two major concerns in ecumenism, namely Faith and Order ${ }^{13}$ and Life and Work, ${ }^{14}$ have both attempted this. For both of them, it is possible to trace a series of successive visions, images, slogans and programmes.

The focus of Faith and Order has been, broadly speaking, on the visible unity of churches in the world, both globally and locally. The ecumenical vision about the nature of this unity to be achieved has, however, shifted over the years. Several descriptions have replaced, complemented and often contradicted one another, including amongst others formulations Zielvorstellungen - like "united, not absorbed," "a communion of communions," "reconciled diversity," "covenant," "sister churches," "organic union," "conciliar fellowship" and "conciliarity."

For obvious reasons, Faith and Order always understood that "efforts towards manifesting the unity of the church" and "efforts towards common witness and service in the world" should "be held together." "Several studies therefore sought to reflect on this relationship, including "The unity of the church and the unity of humankind" and "The community of women and men in the church." Ongoing criticism prompted a study programme called "The unity of the church and the renewal of human community," which led, after a long process and many consultations, to the 1990-document Church and World. The Unity of the Church and the Renewal of Human Community.

This document begins with an analysis of "The human situation and the Christian response," describing "the world today" in terms of both local and global "opportunities and dangers, hopes and anxieties." Christians and churches live in this world and share in these anxieties and hopes. Called to "become what it is," the church knows that "this striving is not for the sake of the church alone," but "it is in and for the world that God calls the church."

The purpose of Church and World is therefore "to affirm and explore this inter-relation of

11. See e.g. Julio de Santa Ana, Konrad Raiser \& Ulrich Duchrow, The Political Economy of the Holy Spirit (Geneva: 1990).

12. See e.g. the informative study by Ernst Conradie, Hope for the Earth. Vistas on a New Century (Bellville, RSA: University of the Western Cape, 2000).

13. See e.g. the informative study by the Dutch Reformed and ecumenical scholar Martien E Brinkman, Progress in Unity? Fifty Years of Theology within the World Council of Churches: 1945-1995. A Study Guide (Louvain: Peeters Press, 1996).

14. For the early years, before the formation of the WCC, see Paul Abrecht, "Life and Work," Dictionary of the Ecumenical Movement, 612-614. Since 1948 it was continued as a separate Unit of the Council, with many desks involved, responsible for a large number of important programmes and projects.

15. See e.g. Dirk J Smit, “Kerkeenheid in die Ekumene,” Apologia 7, 1992, 43-52; Harding Meyer, Ökumenische Zielvorstellungen (Göttingen: Vandenhoeck \& Ruprecht, 1996).

16. Church and world. The unity of the church and the renewal of human community, Faith and Order Paper No. 151 (Geneva: WCC, 1990), vii. 
two fundamental ecumenical tasks: the search for the visible unity of Christ's Church, and the search for common Christian proclamation, witness and service as expressions of God's mission and love for a world crying out for renewal."

The guiding questions, however, remain ecclesiological and the main argument of the document also. The (identity and task of the) church is understood within the perspective of the kingdom of God (as God's creative, redeeming and sustaining rule), as both mystery (with emphasis on the reality of the church as body of Christ) and prophetic sign (with emphasis on the church's role as instrument of God's grace given to a world crying out for healing and renewal), pointing (doxologically) towards an eschatological realization of God's saving purpose for all humankind.

The focus of Life and Work, on the other hand, has been, broadly speaking, on furthering justice in the world. Again, diverse, successive, and sometimes competing notions have served as visions for this endeavour. They included, amongst others, the idealistic and often activist symbol of "the kingdom of God in society" in the early years, the notion of "a responsible society" just after the Second World War, the calling of the church "in periods of rapid social change" in the early 1950s, and during "(technical and social) revolutionary situations" during the 1960s, a church working with enthusiasm and optimism, together with the world, for "development" during the early 1970s, only to become disillusioned and therefore active in the struggles for "liberation ecumenism" from the underside of history during the 1970s, a church dedicated to a long-term Just, Participatory and Sustainable Society-Programme (JPSS) between 1977 and 1983, and since 1983 a comprehensive process to work for Justice, Peace and the Integrity of Creation (JPIC).

These successive visions for the struggle for justice in the world obviously depended to a large extent on the ever-changing analyses of the context in which the ecumenical church found itself. The continuously changing nature of the world called for changes in the nature of the engagement and priorities of the church. It is therefore only to be expected that the accelerating process of globalisation would have a similar effect.

For those involved in Life and Work, ecclesiological issues, including the visible unity of the church, were often regarded as irrelevant, sometimes even obstructive, but in any case secondary. At the most, ecclesial unity would sometimes be regarded as necessary for practical reasons, to make the collective efforts of the churches stronger, in the face of the enormous social, political and economic challenges they were facing. A statement of the first Life and Work Conference, in 1925 in Stockholm, already admitted that "The sins and sorrows, the struggles and losses of the Great War and since have compelled the Christian Churches to recognize, humbly and with shame, that 'the world is too strong for a divided Church". ${ }^{17}$ Later, South African Archbishop Desmond Tutu would allude to this, saying that "apartheid was too strong for a divided church." ${ }^{18}$ The interest in visible unity was functional and practical. The primary focus was ethical rather than ecclesiological.

A major meeting in the Life and Work tradition was held in Seoul, in 1990, with a view "to engage member churches in a conciliar process of mutual commitment (covenant) to justice, peace and the integrity of creation." ${ }^{, 19}$ The two expressions "conciliar process" and "covenant" are ecclesiologically very significant and together demonstrate the underlying intention to commit churches in a unified and in some sense mutually binding manner to confront the life-

17. Edward Shillito, Life and Work: the Universal Conference on Life and Work held in Stockholm, 1925 (London: Longmans, Green and Co., 1926), 96.

18. Archbishop Desmond Tutu, "Towards koinonia in faith, life and witness," in Thomas F Best \& Günther

Gassmans (eds.), On the Way to Fuller Koinonia (Geneva: WCC 1994), 96.

19. See Now is the Time: Final Document and Other Texts (Geneva: WCC 1990). 
and-death issues of the time. However, the result was again lack of integration between the two sets of concerns.

During the last decade voices grew stronger - from both sides - that these two emphases belong together and that the tension between the struggles for unity and justice should be overcome. From different sides the conviction seemed to grow that the notion of koinonia - the Greek word indicating something like communion, community, sharing, fellowship, society, participation, solidarity, Gemeinschaft, but precisely because of the crucial differences caused by any translation deliberately kept untranslated in the earlier study documents $-{ }^{20}$ could serve as a vision integrating these two concerns. ${ }^{21}$

The seventh assembly of the WCC in Canberra (1991) already issued "The Canberra Statement," using the notion of koinonia to set the unity of the church in the broader context of God's design. ${ }^{22}$

The Fifth World Conference of Faith and Order met in Santiago de Compostela in 1993 to draw out and develop this picture of visible unity painted at Canberra. The notion of koinonia played a major role in the proceedings. Its official report was also published under the title $\mathrm{On}$ the way to Fuller Koinonia. ${ }^{23}$ The Conference discussed an overall theme, namely koinonia (understanding koinonia and its implications, including its Biblical witness and perspectives from tradition), with three subthemes, koinonia in faith ("Confessing the one faith to God's glory"), in life ("Sharing a common life in Christ") and in witness ("Called to common witness for a Renewed World").

Two documents from this World Conference are of special importance for understanding the role of koinonia as an overall and integrating vision, namely a preparatory document, widely discussed and often revised, but eventually called Towards Koinonia in Faith, Life and Witness $^{24}$ and the final official Message of the World Conference, called "On the Way to Fuller Koinonia." 25

There can be little doubt that globalisation played a major role in bringing the Ecumenical Movement to this point ${ }^{26}$ where it is seriously striving to combine ecclesiological and ethical concerns under the vision of koinonia. There have obviously always been those in ecumenism who suffered under this unresolved tension and often open - also bureaucratic - animosity, and

20. The Dublin-text for Faith and Order, a draft intended for discussion, still only transliterated the Greek "so as to avoid slanting its meaning" (p. 4). For an excellent discussion of the meanings, and the different uses in the Biblical contexts, see John Reumann, "Koinonia in Scripture: Survey of Biblical Texts," in On the Way to Fuller Koinonia, 37-69.

21. For the recent popularity of the notion of koinonia in ecumenical circles, see George Vandervelde, "Koinonia ecclesiology” ecumenical breakthrough?" One in Christ 29 (1993) 126-142; Susan Wood, "Ecclesial koinonia in ecumenical dialogues," One in Christ 30 (1994): 124-145. Also very insightful is George Vandervelde, "Koinonia between Church and World," Exchange Vol. 26 No. 1, 2-39.

22. See The Unity of the Church as Koinonia: Ecumenical Perspectives on the 1991 Canberra Statement on Unity, a study document requested by the Joint Working Group, eds. Günther Gassmann \& John A Rodano, Faith and Order Paper No. 163 (Geneva: WCC, 1993).

23. Thomas F Best \& Günther Gassmann (eds.), On the Way to Fuller Koinonia (Geneva: WCC, 1994).

24. Published separately as Faith and Order Paper 161 (Geneva: WCC, 1993), but also again included in On the Way to Fuller Koinonia, 263-295.

25. In On the Way to Fuller Koinonia, 225-227. The three Section Reports are found on pages 229-262, and the Discussion Paper is reprinted on pages 263-295.

26. Ecumenism is one facet of the process of integration and internationalisation that has long been a feature of human history, most notably during the periods 1870 to 1920 (which lead to the eradication of various natural borders with inventions such as the steamship, telegraph, railroad and telephone) and from after the second world war to today (which has seen massive increases in the flow of goods and information). It is interesting to note that these were also the periods during which the activities of the Ecumenical Movement expanded most rapidly. 
who always wanted to bridge this divide. ${ }^{27}$ The urgency of the last decade, however, has certainly been brought about by an awareness - sometimes described as "a fundamental shift in historical consciousness, felt in both spheres of ecclesiology and ethics ... that presuppositions that have been taken for granted in the past, regarding both the church and its selfunderstanding as well as the forming of ethical judgments, are beginning to crumble"28 changes are taking place in the world that challenge the ecumenical church in a more fundamental way than ever before.

The preparatory Discussion Paper, for example, introduces its work with a description of "The search for communion in a time of change" and explains: "The pilgrimage towards koinonia in faith, life and witness takes place in an ever changing world and ecumenical situation ... Some believe that the real global revolution of our epoch is only just beginning" followed by a detailed description of the phenomena usually understood as part of globalisation. ${ }^{29}$

\section{Ecclesiology and ethics?}

The deliberate purpose behind this recent focus on koinonia is therefore the attempt to bring ecclesiological and ethical concerns together in a new and fruitful way. Three consultations were held as part of this process, jointly organised by Units I (Faith and Order) and III (Justice, Peace and the Integrity of Creation) of the WCC.

Their three final statements were published together as Ecclesiology and Ethics. Since they are called "Costly Unity," "Costly Commitment," and "Costly Obedience," respectively, the ecclesiology and ethics-project has been described as "A litany of "costlies"".

"Costly Unity" is the report of a first meeting in Rønde, Denmark, in $1993 .{ }^{30}$ The explicit purpose is serious dialogue about these "long-lived tensions and divisions," this "cleft ... exposing a history of differences which runs the length of the modern ecumenical movement."

To achieve that, they propose to see the church itself as moral community. "It all comes to the same point: the church not only has, but is, a social ethic, a koinonia ethic."

"The being (esse) of the church is at stake in the justice, peace and integrity of creation process" and "koinonia," they argue, "is an apt term for both." The major part of the document consists of an exposition, under different headings, of the nature of such koinonia and its implications.

"Cheap unity" avoids morally contested issues because they would disturb the unity of the church. Costly unity in the church as moral community is discovering the churches' unity as a gift of pursuing justice and peace. It is often acquired at a price.

Church as moral community begins with the moral meaning of the sacraments themselves. The sacraments as person-shaping rites can lead into sacramental living. The bridge between ecclesiology and ethics is to be found in the experience of worship and the deepening of spirituality.

This report served a few months later at Santiago de Compostela and contributed to the important role that koinonia as integrating notion would play there. Already, however, a second

27. The metaphor of "a bridge" and "bridging" is often used to describe the task ahead, see e.g. Thomas F Best \& Martin Robra (eds.), Ecclesiology and Ethics. Ecumenical Ethical Engagement, Moral Formation and the Nature of the Church (Geneva: WCC 1997), "Introduction," vii-xii.

28. See e.g. Konrad Raiser, "Ecumenical Discussion of Ethics and Ecclesiology," The Ecumenical Review Vol. 48, 1996, 3-10.

29. Towards Koinonia in faith, Life and Witness (Geneva: WCC 1993), 7-8.

30. For a full report, see Thomas F Best \& Wesley Gramberg-Michaelson, eds., Costly Unity: Koinonia and Justice, Peace and Creation (Geneva: WCC 1993). 
joint meeting was planned, partly because the idea of the church as a moral community was unclear and led to many questions and criticisms.

"Costly Commitment" is the report of this second meeting at the Tantur Ecumenical Institute in Jerusalem, Israel, in $1994 .{ }^{31}$ Part of the problem with the description of the church as moral community is that it may seem like a description of what is already and always the case, particularly when it builds on the experiences of the sacraments, worship and spirituality. This would not sufficiently account for the many differences between churches, and for their lack of ethical involvement.

Accordingly, they want to emphasise the calling, the vocation, of the church. The churches - even as moral communities - are called to commit themselves to one another, recognising that they need one another on their ecumenical journey. Such commitment is an essential foundation for their common reflection and action. It becomes increasingly clear - they claimthat the road to costly unity leads necessarily to a costly commitment of the churches to one another. Those who have previously been wary of "moral reductionism" should commit themselves to the ethical character of the church. Those who have been deeply engaged in ethical praxis only, should commit themselves also to ecclesial renewal.

Explaining what such mutual costly commitment would entail, the document develops several notions. It emphasises the crucial importance of this ecumenical commitment for being the church - and asks whether churches could still call themselves "church" if they are not committed to this joint process. In particular, they suggest notions of moral formation and moral discernment to flesh out the too abstract notion of a moral community. Moral formation, as part of the churches' overall task of spiritual formation, would train church members in discernment, helping them to analyse ethical issues from the perspective of the gospel, preparing them best to participate in the light of their faith in the moral struggles, complexities and challenges of the present day, and thus making it possible for the churches to contribute to the moral well-being of the societies in which they live, for example through informed participation in public debate on specific ethical issues. The fraying of the moral fibre in many societies - says the document - makes this role all the more urgent today.

Although the major part of "Costly Commitment" is devoted to develop "the language" of moral formation and discernment and to demonstrate in how many ways such language could prove useful to understand the nature of the koinonia, it concludes that much more needs to be done in this regard, and that happens at a third and final consultation.

"Costly Obedience" is the report of this third and final meeting in Johannesburg, South Africa, in 1996. ${ }^{32}$ The theme of moral formation is further pursued by asking "what it might mean to speak of the church as a global communion of moral witnessing."

The obedience to which the church is called - it is said - is often costly. It may require the churches to position themselves in relation to the issues of particular times and places in ways which call for courage, perseverance and sacrifice. Such faithfulness may even come to the point of martyrdom.

Again, the consultation finds it necessary, but difficult, to interpret the particular time and place, and does that in terms of globalisation. ${ }^{33}$ In the light of this description, the document

31. For a full report, see Thomas F Best \& Martin Robra, eds., Costly Commitment: Ecclesiology and Ethics (Geneva: WCC 1995), with the papers also available in Ecumenical Review Vol. 47, 1995, 127-187.

32. For the basis document discussed at the Meeting, see Lewis S Mudge, "Ecclesiology and ethics in current ecumenical debate," Ecumenical Review 1996, 11-27. For four of the papers presented (by John W de Gruchy, Margot Kässmann, Vigen Guroian and Duncan B Forrester) see Ecumenical Review Vol. 49, 1997, 356-383. For the Statement, see Ecclesiology and Ethics, 50-89.

33. "We are rapidly becoming a global community, yet a community constituted by dehumanizing economic and 
then discusses at some length the meaning of moral formation in the world, the churches' moral failure in face of nationalistic, ethnic and economic violence, the grounding of the church's moral formation in the eucharist and baptism, and finally the idea of an ecumenical moral communion and the possible role of the WCC in such an endeavour.

In summary, this study process - at least partly caused by the impact and challenge of globalisation on ecumenism - sought to explore the link between what the church is and what the church does, and in doing this, both these aspects have also come under scrutiny and critical reflection. The koinonia to which the oekumene is called, which involves communion in faith, in life and in witness, takes the form of costly unity - which means that faith involves discipleship - and calls the churches to costly commitment to one another, as well as to costly obedience, facing the struggles for life of every age.

It has become clear that, in the face of globalisation, the Ecumenical Movement is challenged to consider - at least - four sets of questions anew. They deal with the calling of the ecumenical church, with the nature of the church, with the nature of ethics, and with the theological competence of the church, respectively.

It is still an open question whether the attempts to integrate ecclesiological and ethical concerns have been successful. It is understandable why criticism of the process and the achievements was forthcoming from different perspectives. More attention to the relationship between identity and responsibility is needed. ${ }^{34}$

Regarding the nature of the church, it has been a helpful development that the WCC has increasingly taken the different concrete forms (Gestalten) more seriously, although not yet in a very systematic fashion. ${ }^{35}$

At least six forms of the church should be distinguished when considering the identity and calling of the church, and accordingly the relationship between the church and globalisation, namely the church as ecumenical church (whether global, national, regional or local), as denomination(s), as (mostly local) congregations, as worshipping communities, as individual believers (in the fullness of their personal, private and public, lives) and as believers

political relationships ... The planetary scale of our human struggle presents challenges beyond any the churches have faced before. Moral issues, formerly seen as having to do mainly with personal conduct within stable orders of value, have become radicalized. They have to do with life. Before we can speak of a 21 st-

century "global civilization", life together on this planet will need shared visions and institutional expressions for which we have few relevant precedents. As Christians we speak of an oikoumene, or inclusive horizon of human belonging, offered by God in Jesus Christ to the human race. Following the scriptures, we call this a "household of life", a "heavenly city" where justice, peace and care for creation's integrity prevail. But what may it mean to live lives in the here and now which manifest the first fruits of these gifts and act in anticipation of their fulfilment?

Christian faith, today as in the past, risks being captured for ethnic and nationalistic purposes. It risks being called on to help protect the privileges and ways of dominant classes. Our brief sojourn in South Africa has suggested to us that the former apartheid regime's theologically constructed defence of racial separation could become an unacknowledged precedent for violence by the rich nations of the northern hemisphere, facing as they do immigration pressures and economic demands from the south and the continuing threat of counter-violence from multitudes of the still-wretched of the earth.

If the church is to fulfil its calling to be a sign of God's reign in such a situation, it is imperative that it begin to understand itself as an ecumenical moral community. Hence the importance of the theme of moral formation. The church needs to ask how - with all its theological, liturgical and sacramental resources - it can be a community of relevant moral witness for such a world," Ecclesiology and Ethics 51-52.

34. Several questions come to mind, for example, whether churches can still call themselves churches if they do not engage themselves in ecumenical efforts, see Ecclesiology and Ethics, 28-29; whether they are still churches if they do not follow their ethical calling in the world; whether it is helpful to speak of ethical heresy, see e.g. Ecclesiology and Ethics, $5 \mathrm{ff}$.

35. For a helpful discussion of this approach, see Wolfgang Huber, Kirche (München: Chr. Kaiser Verlag), 44-58. 
participating in initiatives and actions, together with others, whether Christian or not, committed to the same cause. In some form or another, all six of these have received attention in the recent study processes and documents.

Regarding the understanding of the ecumenical church itself, the impact of globalisation has perhaps been the most dramatic. A concrete illustration is "the several years of sustained theological reflection" as "an ongoing journey of self-reflection on the nature and purpose of the ecumenical movement," leading to the comprehensive policy statement "Towards a Common Understanding and Vision of the World Council of Churches," presented to the Eight Assembly in Harare. ${ }^{36}$ Ecumenism is most certainly in a time of transition. ${ }^{37}$

Among the many important issues to be considered here, ${ }^{38}$ is that of reception, sometimes called the single most difficult issue for ecumenism. When and how do churches, congregations and believers adequately "receive" the studies, documents, and decisions produced at the ecumenical level? ${ }^{39}$

The nature, the role, the importance and future of denominations and confessional traditions have all been addressed in new ways, with a new awareness for their significance, in recent documents. The visible structures of a church, its polity and order, its bureaucracy and everyday activities can witness to or contradict the gospel. To take the real church (die wirkliche Kirche) seriously, one has to take serious the relationships between message and structure (das Verhältnis von Botschaft und Ordnung - als Grundproblem evangelischen Kirchenverständnisses), between truth-claims and ways-of-existence (Wahrheit und Existenzform $){ }^{40}$ Indeed, a polity is already an ethic. ${ }^{41}$

In a time of weakening ecumenical and even denominational commitment, the role of local congregations has become extremely important. This is where the effect of globalisation called glocalisation by the leading theorist Roland Robertson ${ }^{42}-$ is perhaps felt the most vividly. This is, however, at the same time the place where a sense of household and belonging could be fostered and where the spiritual en moral formation so sorely needed could take place, if at all. ${ }^{43}$

In a remarkable way, ecumenical reflections have recently emphasised the role of worship. Traditionally, the ecumenical and liturgical movements went hand in hand. Several essays in the extremely valuable collection of the longstanding ecumenical theologian, Geoffrey

36. See the document and a discussion in The Ecumenical Review Vol. 51, 1999, 96-113.

37. See the title of Konrad Raiser's essays, already published in 1991 (German 1989), on a paradigm shift in ecumenism, Ecumenism in Transition (Geneva: WCC 1991). Since then Raiser has regularly made significant contributions in this regard, often in The Ecumenical Review, but also in the more popular To be the Church. Challenges and Hopes for a New Millennium (Geneva: WCC 1997).

38. In general, see the discussion of "The World Council of Churches as marker and space-maker for an ecumenical moral communion," Ecclesiology and Ethics, 76-87.

39. See Piet J Naudé \& Dirk J Smit, "Reception - an ecumenical crisis or opportunity for South African churches?," Scriptura 73, 2000:2, 175-188 (with literature).

40. The references are to different essays by Wolfgang Huber in his collection, Folgen christlicher Freiheit (Neukirchen: Neukirchener Verlag 1983), all developed in conversation with Barmen and Bonhoeffer. These ideas have played a crucial role in the Church Order of the new Uniting Reformed Church in Southern Africa, established on the basis of the Confession of Belhar (1986), in the tradition of Barmen.

41. Ecclesiology and Ethics, 45.

42. Robertson preserves attention to both locality and globality, also called particularism and universalism, by arguing for "a massive, twofold process involving the interpenetration of the universalization of particularism and the particularization of universalism" (Roland Robertson, Globalization: Social Theory and Global Culture, London: Sage 1992, 100).

43. See e.g. the discussions of "The local and the global" and "Diversity and unity" in Ecclesiology and Ethics, 13-15. 
Wainwright, Worship with One Accord, ${ }^{44}$ tell the story of this close connection, as does the rest of his theological work. ${ }^{45}$ Worship also almost always played a major role in the activities of the Ecumenical Movement. In recent years, however, a new awareness of the importance of worship - the eucharist, but also understood in a broader sense - for formation has become visible. $^{46}$

That the church also - according to some Protestant views: ultimately - consists of individual believers has seldom been the main focus of attention in the Ecumenical Movement, precisely because of its understandable concern with national and transnational involvement and activities. Challenged by the impact of late-modernism - in forms such as spreading secularisation, radical individualism, and destructive pluralisms - and globalisation, the realisation is growing that believers have important roles to play in building up - a diverse number of - households of life in the contemporary world.

Finally, several recent ecumenical documents raise serious ecclesiological questions regarding their experiences - including those of real koinonia - while participating, outside the traditional spheres of the church, in diverse civil and public initiatives and activities, ${ }^{47}$ together with people of other persuasions and religious convictions, but sharing the same moral commitments. ${ }^{48}$

Regarding the nature of ethics, it has also been extremely helpful that the Ecumenical Movement is challenged to consider the complexity of morality and ethics more fully than often before, when it seemed fairly clear what Christians, irrespective of tradition or confession (since "doctrine divides but service unites"), should be doing in the world.

Challenged to analyse and understand why Christians and churches do disagree with one another on moral issues, the Ecumenical Movement has distinguished between different moral quests and approaches - on visions, values, virtues, and obligations - and pointed to different moral environments, different sources for and pathways to moral deliberation, and different authoritative means of moral discernment. ${ }^{49}$ All these insights represent valuable progress on the way to responsible ecclesial life - including formation, decision-making, witness and involvement - in the new globalising world.

44. Geoffrey Wainwright, Worship with One Accord: Where Liturgy and Ecumenism Embrace (New York: Oxford University Press, 1997).

45. See Dirk J Smit, "Spirituality, worship, confession, and church unity: A story from South Africa" in Ecumenical Theology in Worship, Doctrine, and Life. Essays Presented to Geoffrey Wainwright on his Sixtieth Birthday, ed. by David S. Cunningham, Ralph Del Colle \& Lucas Lamadrid (New York: Oxford University Press 1999), 271-281.

46. For related discussions from a South African perspective, see Dirk J Smit, "The Church and Civil Society," unpublished paper, 1996-EFSA Conference; and Dirk J Smit, "Liturgy and Life? On the importance of worship for Christian ethics," Scriptura 1997:3, 259-280. See also the valuable collection by Duncan Forrester, The True Church and Morality. Reflections on Ecclesiology and Ethics (Geneva: WCC 1997).

47. See e.g. the discussion of "relationships with movements and groups" in "Costly Unity," Ecclesiology and Ethics, $15 \mathrm{ff}$.

48. For many, the question is obviously whether these movements do not represent the real church. E.g. "It is an empirically verifiable observation that commitment to and working for particular moral causes creates community among people. The experience of JPIC again and again has been that people have been gathered into a fellowship which can be described as koinonia. Involvement in these struggles of human community generates this koinonia and often enlightens doctrine. An "ecclesio-genetic" power is at work here, frequently moving participants to rich liturgical expression and raising deep religious questions for them, questions of faith and commitment. The power of the Holy Spirit is present here - this is the testimony," Ecclesiology and Ethics, 4, and again 33-36. During the struggle against apartheid, many South Africans, including ministers, have made similar experiences and faced similar questions.

49. See the very useful paper, The Ecumenical Dialogue on Moral Issues. Potential Sources of Common Witness or of Divisions. A Study Document of the Joint Working Group between the Roman Catholic Church and the World Council of Churches (Geneva: WCC 1996), also published in The Ecumenical Review Vol. 48, 1996. 
With that, the fourth set of issues has already been touched on, namely those questions that concern the specific competency of the church as church. What can the church do, that others can not do? Or what could and should the church as church be doing? What does the church as church have to contribute? What does the church know as church?

These are serious questions, because the church's involvement - particularly that of the ecumenical church - in public affairs, whether internationally, nationally or locally, is only too often seen as merely an endorsement of or support for specific ideological or interest groups. There can be little doubt that many people, including members of the church, have become very sceptical of the church's role in public life, whether it is supportive and providing legitimacy, critical and prophetic, or activist and advocatory. The church often lacks credibility. Even theologians involved in ethics are often seen as nothing more that "social scientists with religious interest.",50

The church is, therefore, challenged to act on the basis of its own theological competence. ${ }^{51}$ This would involve at least three challenges. The church should rethink its own contribution, its communication, and its commitments. Put in the form of questions:

Firstly, what does the church as church know? What theological perspective and contribution can the church offer? Recent attempts to link ethics to ecclesiology, even to Trinitarian theological insights and convictions - however controversial these attempts may still be - offer challenging beginnings in this respect.

Secondly, how does the church speak about public - also "global" (Robertson) - issues? To whom does she speak? With what kind of authority? With what kind of expectation? Acknowledgement that the church is in a process of learning to speak in new, and more acceptable, responsible and hopefully meaningful ways in the new world is one of the valuable insigts gained. ${ }^{52}$ The thorny issue of teaching authority has always been on the ecumenical agenda, but its importance for ethics has suddenly become central. ${ }^{53}$

Thirdly, what does the church do about these challenging global issues? How does the church get involved? And even more fundamentally, how credibly does the church demonstrate its own convictions in its own structures, life and activities?

Remarkably enough, a certain optimism regarding the ecumenical church precisely in the face of globalisation can be detected from time to time. The North American Lutheran and ecumenical ethicist, Larry Rasmussen, for examples reminds readers of his excellent study, Moral Fragments and Moral Community, that "(F)ew communities are better poised geographically or by virtue of their vocation. Spin the globe and stab your finger to stop it and you probably put your first digit through the roof of somebody's church somewhere. When we most need institutions that are as local as the neighbourhood and as global as the planet itself, we have at least one transnational body already on the job whose very calling it is to gather all, on equal terms, into caring community across barriers that divide." ${ }^{54}$ On a national level, it is often said in South Africa that the church has an organisation equal to none for playing a

50. In the cynical words of Stanley Hauerwas, "On keeping theological ethics theological," Against the Nations (Minneapolis: Winston-Seabury Press 1985), 28.

51. This is an underlying theme in the extremely valuable recent study by Wolfgang Huber, Kirche in der Zeitenwende. Gesellschaftliche Wandel und Erneuerung der Kirche (Gütersloh: Verlag Bertelsmann Stiftung).

52. Cf. e.g. the very insightful study by the British ecumenical theologian Keith Clements, Learning to Speak. The Church's Voice in Public Affairs (Edinburgh: T \& T Clark 1995).

53. For an instructive overview of earlier discussions, see Anton Houtepen, "Teaching authority," Dictionary of the Ecumenical Movement (Geneva: WCC, 1991), 970-973, with literature.

54. Larry Rasmussen, Moral Fragments and Moral Community. A Proposal for Church in Society (Minneapolis: Augsburg Fortress, 1993), 150. 
meaningful role in civil society, in social welfare, education, and many other spheres of life.

\section{Globalisation and/as community - and ecumenism?}

Widely accepted popular opinion holds that modern societies often lack meaningful experiences of community, of solidarity, of fellowship, support, and care. From different positions and perspectives, and for a wide diversity of reasons - social critics, commentators, analysts, politicans, philosophers, and sociologists, since Tönnies and Durkheim - have all bemoaned the lack of community in typically modern societies.

It is perhaps not far-fetched to suggest that globalisation claims to produce not only a new Weltgesellschaft, but also a new experience and reality of Weltgemeinschaft, a new sense of community, belonging, identity. Slogans like "global village" and "world civilization" all seem to carry this suggestion. Descriptions of globalisation like "the way in which relations of power and communication are stretched across the globe, involving compressions of time and space and a recomposition of social relationships $", 55$ seem to point in such a direction. What is at stake is not merely the physics of our information age and of globalisation, but its metaphysics, "its significance to individual and social morality ... and its consequences for the formation, maintenance and alteration of personal identity. ${ }^{, 56}$

In a very interesting study, Robert J Schreiter, a well-known North American Catholic scholar explores the challenges and opportunities of globalisation under the significant title The new catholicity. His thesis is that "the issue today is catholicity." According to him, the church should respond by adding "communication" - including issues of culture, identity, and social change - as a third an necessary element of an enlarged concept of catholicity to the earlier, traditional elements of "extension throughout the world" and "fullness of faith."

It is, however, also possible to argue that the issue today is catholicity, precisely because globalisation itself presents a form of catholicity, making the claims of universality in space, culture and time, of fullness of truth, of unity and wholeness, and of rule and authority, which the Greek katholikos, "that which belongs to the whole" or "that which comprehends the whole or the totality" has traditionally made. ${ }^{58}$

From a religious and moral perspective, it is possible to argue that the real challenges embedded in globalisation concern not so much what we $d o$, but who we are, who we are becoming, what the nature of the communion is that we experience, and whether these represent the kind of people we want to be and the kind of communion we want to be part of. What is ultimately at stake, may be the kind of koinonia we are, the nature of the household and households we belong to.

It is precisely for this reason that globalisation is challenging the Ecumenical Movement to rethink its traditional ecclesiological and ethical concerns in the perspective of koinonia and oikos. In the words of Konrad Raiser, Secretary-General of the WCC, developing the apostle Paul's image of oikodomé, that is, mutual upbuilding:

"The central challenge today, both for the understanding of the church and for ethics, is to promote the rebuilding of sustainable communities ... Underlying this is the quest for a new

55. Ali Mohammed (ed.), International Communication and Globalization (London: Sage, 1997), 3.

56. See Chris Arthur, The Globalization of Communications (Geneva: WCC 1998), 1-3, but also the rest of the study.

57. Robert J Schreiter, The New Catholicity. Theology between the Global and the Local (Maryknoll, NY: Orbis, 1998).

58. For an excellent introduction to the traditional view of catholicity, see Willie D Jonker, "Catholicity, unity and truth," in Paul G Schrotenboer, ed., Catholicity and Secession. A Dilemma? (Kampen: Kok, 1992), 16-27. 
ethics of life in relationships, and the concept of oikodomé could give direction to this quest. Oikodomé as the building up of the community aims to strengthen the church as a fellowship of hope, solidarity and trust in which the rules of a new life-centred culture and ethic can be developed and practised." ${ }^{, 59}$

Almost every word in this quotation is important. It falls outside the scope of this paper, but for ecumenical theological reflection such a challenge would - as a minimum - imply that ecumenism should develop its own theological understanding of community, in order to analyse and where necessary engage the kind of community produced, spread and offered by processes of globalisation. The informative contribution by Heinrich Bedford-Strohm, Gemeinschaft aus kommunikativer Freiheit. Sozialer Zusammenhalt in der modernen Gesellschaft. Ein theologischer Beitrag, in which he attempts to do exactly this with regard to typically modern societies, especially Germany, could serve as a helpful illustration of the task that lies ahead. ${ }^{60}$

\section{A South African postscript}

To conclude, a few comments from a - very particular - South African theological perspective. In 1982, the (then) Dutch Reformed Mission Church drafted a confession of faith, rejecting the theology of apartheid in the light of its own understanding of the Christian gospel. ${ }^{61}$

Based on convictions living in the hearts of its members, the Confession of Belhar followed a threefold logic of confession. God is praised as the One who gives unity to the church and calls the church to practise this unity; as the One who reconciles believers with Godself and with one another and calls them to practise this reconciliation; as the One who is in a special way the God of the suffering, the downtrodden, and the oppressed and calls the church to follow Him in this. Doxological statements about God thus lead to ecclesiology and then to ethics.

On the basis of their faith, these believers rejected apartheid theology, ideology and practice - although apartheid was deliberately nowhere mentioned - in the name of living unity, real reconciliation and caring justice - even if this should lead to costly obedience, as confessed in a concluding section.

Looking back, it is obvious that the remarkable impact of Belhar - at least amongst the members of the (now) Uniting Reformed Church in Southern Africa - was made possible by

59. Konrad Raiser, "Ecumenical discussion of ethics and ecclesiology,” Ecumenical Review 1996, 9ff. Raiser, in turn, is making use of the work of the well-known ecumenist Geiko Müller-Fahrenholz, God's Spirit: Transforming a World in Crisis, tr. J Cumming (Geneva: WCC \& New York: Crossroad, 1995).

60. Heinrich Bedford-Strohm, Gemeinschaft aus kommunikativer Freiheit. Sozialer Zusammenhalt in der modernen Gesellschaft. Ein theologischer Beitrag (Gütersloh: Chr. Kaiser/Gütersloher Verlagshaus, 1999). In a first major part, he considers the often presumed lack or the changed nature of community (Gemeinschaft) in modern societies from a sociological perspective. He does this in four steps, by discussing Tönnies, Durkheim, Ulrich Beck and Elisabeth Beck-Gernsheim theory of individualisation, and a wide variety of empirical surveys. In a second major part, he uses a theological-ethical approach, asking about the nature of Christian love as basis for community. Starting with the popular although now discredited distinction between agape and eros, he moves on to discuss a number of burning questions concerning Christian love. In a final section, he employs his insights to argue for a form of community in modern societies that builds on the notion of "communicative freedom" in dealing constructively with pluralism. In this way, he develops the ideas of civil society, reciprocity and public church, informed by theological competence but directed at urgent contemporary social questions.

61. For information, see Dirk J Smit, “Das Bekenntnis von Belhar: Entstehung, Inhalt, Rezeption, Relevanz,” Das Bekenntnis von Belhar und seine Bedeutung für die reformierten Kirchen in Deutschland (Detmold: Lippische Landeskirche 1998), 17-33. 
the inter-relationship between these three, by the realisation and claim that living unity, real reconciliation and caring justice integrally belong together. The one cannot be achieved without the other.

It is not difficult to see that precisely these issues have remained the overwhelming challenges in post-apartheid South Africa. It is even possible to argue that this society successively went through three phases of transformation, in which these issues were at stake.

The first phase was the after-Babel period in which a deeply fragmented society had to establish and cement a newly found unity, in the form of a constitutional democracy. The second phase was the Mandela-period of reconciliation in which people had to become reconciled with one another, with themselves and their memories, and with their present situations and future expectations. In many ways, this period was symbolised by the work of the Truth and Reconciliation Commission and its Chairperson, Archbishop Tutu. The third phase is the Mbeki-period or real transformation and renaissance towards economic justice, self-respect and dignity.

It is also clear that the subsequent phases did not replace the earlier ones, on the contrary. The challenges concerning living unity and real reconciliation remain as urgent as the challenge of caring justice.

If the insights gained from the developments in the ecumenical movement in the face of globalisation make sense, the contribution of the URCSA to ecumenical and public moral discourse in South Africa could consist in the first place in making use of its own theological competency, in speaking the language of unity, reconciliation and justice, and reminding themselves and others that these three belong together.

In the second and third place, the URCSA should face questions concerning its communication of these convictions, and questions concerning its own life, witness and activities in the service of unity, reconciliation and justice.

Concerning caring justice, the URCSA has already through Belhar contributed to ecumenical and public discourse, both in South Africa and in the ecumenical movement. ${ }^{62}$

It may be necessary for the URCSA, on the basis of its own confession, to witness to the remaining urgency of the need and challenge to work for real reconciliation. In the Ecclesiology and Ethics-study project, some voices, particularly from the margins, reminded from time to time that "costly reconciliation" should not be forgotten. ${ }^{63}$ The URCSA would agree with this. "You cannot aim at unity without working for reconciliation, you cannot expect reconciliation to happen without justice. ${ }^{" 64}$ The three belong together, and in situations with histories of oppression, exclusion, violence and suffering, working for reconciliation may be costly indeed.

Facing globalisation and its own claims concerning community, however, it is perhaps time

62. The URCSA has for example been deeply involved in the study process that led to the decision of the World Alliance of Reformed Churches to declare a processus confessionis regarding world economic injustice and ecological destruction, during its 23rd General Council, in Debrecen, in 1997. See Dirk J Smit, "A time for confession? On the WARC project 'Reformed Faith and Economic Justice”, unpublished paper, Theological Society of Southern Africa, 1999.

Several Churches outside Southern Africa have also taken Belhar seriously in one way or another, including the Uniting Protestant Church in Belgium, and the Reformierter Bund (and its members) and, recently, the Evangelische Kirche der Union.

63. See e.g. Elizabeth S Tapia's closing comment in "Reflections of a Filipina Christian," Ecclesiology and Ethics, 112-117.

64. Russel Botman, in his speech to the Synod of the Evangelical Church of the Union (EKU), May 4-6, 2000, in Berlin, on the theme "With Barmen beyond Barmen." 
for the URCSA to call to mind its own explication of living unity, of koinonia. ${ }^{65}$ Living unity according to the Christian vision calls for more than what globalisation seems to be able to offer. Living unity calls for more than the unity of democratic structures, whether legal, political and bureaucratic, and the unity of globalisation, whether driven by the market or by technology and communication. In themselves these structures and processes do not guarantee the kind of living unity, of koinonia, that the church longs for, the world is in need of, and we believe we are called to serve.

65. We believe that Christ's work of reconciliation is made manifest in the Church as the community of believers who have been reconciled with God and with one another;

- that unity is, therefore, both a gift and an obligation for the Church of Jesus Christ; that through the working of God's Spirit it is a binding force, yet simultaneously a reality which must be earnestly pursued and sought: one which the people of God must continually be built up to attain;

- that this unity must become visible so that the world may believe; that separation, enmity and hatred between people and groups is sin which Christ has already conquered, and accordingly that anything which threatens this unity may have no place in the Church and must be resisted;

- that this unity of the people of God must be manifested and be active in a variety of ways: in that we love one another; that we experience, practice and pursue community with one another; that we are obligated to give ourselves willingly and joyfully to be of benefit and blessing to one another; that we share one faith, have one calling, are of one soul and one mind; have one God and Father, are filled with one Spirit, are baptised with one baptism, eat of one bread and drink of one cup, confess one Name, are obedient to one Lord, work for one cause, and share one hope; together come to know the height and the breadth and the depth of the love of Christ; together are built up to the stature of Christ, to the new humanity; together know and bear one another's burdens, thereby fulfilling the law of Christ; that we need one another and upbuild one another, admonishing and comforting one another; that we suffer with one another for the sake of righteousness; pray together; together serve God in this world; and together fight against all which may threaten or hinder this unity;

- that this unity can be established only in freedom and not under constraint; that the variety of spiritual gifts, opportunities, backgrounds, convictions, as well as the various languages and cultures, are by virtue of the reconciliation in Christ, opportunities for mutual service and enrichment within the one visible people of God;

- that true faith in Jesus Christ is the only condition for membership of this Church;

- Therefore, we reject any doctrine which absolutises either natural diversity or the sinful separation of people in such a way that this absolutisation hinders or breaks the visible and active unity of the Church, or even leads to the establishment of a separate church formation;

- which professes that this spiritual unity is truly being maintained in the bond of peace whilst believers of the same confession are in effect alienated from one another for the sake of diversity and in despair of reconciliation; which denies that a refusal earnestly to pursue this visible unity as a priceless gift is sin; which explicitly or implicitly maintains that descent or any other human or social factor should be consideration in determining membership of the Church. 